\title{
Impact of Essential Micronutrient, Zn, on Growth and Chlorophyll Biosynthesis in Young Zea mays Seedlings
}

\author{
R. (Chinchalkar) Waghmare, R. Gadre* \\ School of Biochemistry, Devi Ahilya University, Takshashila Campus, Indore, India \\ Email: *rekhagadre29@gmail.com
}

How to cite this paper: Waghmare, R.C. and Gadre, R. (2018) Impact of Essential Micronutrient, $\mathrm{Zn}$, on Growth and Chlorophyll Biosynthesis in Young Zea mays Seedlings. American Journal of Plant Sciences, 9, 1855-1867.

https://doi.org/10.4236/ajps.2018.99135

Received: July 6, 2018

Accepted: August 18, 2018

Published: August 21, 2018

Copyright ( 92018 by authors and Scientific Research Publishing Inc. This work is licensed under the Creative Commons Attribution International License (CC BY 4.0).

http://creativecommons.org/licenses/by/4.0/

\begin{abstract}
The present study analyses growth and chlorophyll biosynthesis in young maize seedlings in response to $\mathrm{Zn}$ supply over a wide range of concentrations. Supply of $0-5 \mathrm{mM} \mathrm{ZnCl}_{2}$ to 3 days old light grown maize seedlings led to gradually increased accumulation of $\mathrm{Zn}$ in the shoot tissue, while in the root tissue substantial increase was observed at/and above $0.1 \mathrm{mM} \mathrm{ZnCl} . \mathrm{Zn}$ supply significantly reduced the overall growth of maize seedlings mostly at 1 - $5 \mathrm{mM} \mathrm{ZnCl}_{2}$ exerting strong correlation and the observed effect was more substantial for root tissue. Amongst the biochemical parameters, increase in protein and proline content was more prominent in root tissue than the shoot, while RNA content was reduced in shoot tissue. Zn treatment to light grown seedlings significantly increased the chlorophyll, carotenoid content, while in dark grown seedlings it had marginal/no effect. Delta amino levulinic acid (ALA) content in both the regimes was increased at higher $\mathrm{Zn}$ concentrations. Also ALA synthesis was increased in both the regimes, but non significantly. Zn enhanced ALA dehydratase (ALAD) activity of light as well as dark grown seedlings being significant in former. The results demonstrate that the $\mathrm{Zn}$ accumulation and growth effect at higher $\mathrm{Zn}$ concentrations in maize depend upon the tissue with root as the target site and shoot growth are mainly influenced by ALA and subsequently ALAD in maize seedlings.
\end{abstract}

\section{Keywords}

Amino Levulinic Acid, Amino Levulinic Acid Dehydratase, Chlorophyll Biosynthesis, Growth Effects, Maize, Zn Effects

\section{Introduction}

Zinc ( $\mathrm{Zn})$ being an essential micronutrient for plants, is required for optimum 
growth and development. Its deficiency as well as toxic symptoms has been found in different plants. Zn deficiency reduces various physiological processes, such as, net photosynthesis [1], tissue water content and $\mathrm{P}$ and $\mathrm{Mg}$ concentrations [2] in plants. Toxic effects of $\mathrm{Zn}$ in plants influencing different functions have also been reported, such as, high concentrations of $\mathrm{Zn}$ decrease net photosynthesis and respiration rate in Beta vulgaris [3], generate reactive oxygen species, and decrease the chlorophyll content and shoot yield [4]. Zn effects on plant growth varies in different species, thus decrease has been observed in ryegrass [5], clusterbean [6], in sugarbeet [7], and in Sorghum [8] while in Eruca sativa seedlings increase is reported [9].

Chlorophylls are the vital pigments being analyzed to assess the impact of deficiency as well as the toxicity of various causative factors. Chlorophylls are one of the essential tetrapyrroles responsible for their light trapping and energy transduction activities. Chlorophyll biosynthesis is a vital physiological process of the green plants, which is regulated at several steps [10]. Its biosynthesis involves a complex pathway having a large number of intermediates with amino levulinic acid (ALA) as the common precursor for all tetrapyrroles. ALA is synthesized by the two pathways, the Shemin pathway involving glycine and succinyl Co-A and the Beale pathway, involving the C-5 compounds, like glutamate and 2-oxoglutarate by an ALA synthesizing system in plants [10]. ALA dehydratase (ALAD, E.C. 4.2.1.24) catalyses the next step i.e. conversion of ALA to porphobilinogen, the basic unit of tetrapyrrole. ALADs from different sources are metalloenzymes that utilize a variety of divalent and monovalent cations [11]. Plant ALAD requires $\mathrm{Mg}^{2+}$ and $\mathrm{Zn}^{2+}$ for its activity. Decrease in chlorophyll content due to Zn supply has been reported in several plant species [6] [7] and [8] and also the photosynthetic activity [5]. However, Zn effects on enzymes of chlorophyll biosynthesis including earlier steps are rare. Early stages of seedling growth are a crucial part of any plant life. Thus, to study impact of $\mathrm{Zn}$ three days old seedlings were used involving hydroponic technique with the objective to evaluate the $\mathrm{Zn}$ effects in relation to growth and chlorophyll biosynthesis in young maize seedlings.

\section{Materials and Methodology}

\subsection{Plant Material and Treatment}

Seeds of Zea mays L. cv. Ganga safed-2, were surface sterilized with $\mathrm{HgCl}_{2}$ (0.1\%) for $1-2$ min followed by thorough washing and then soaked in distilled water for half an hour. About 20 seeds were placed in petri plates lined with moistened whatman filter paper and the seedlings were grown for three days in continuous light of $30 \mathrm{Wm}^{-2}$ at $26^{\circ} \mathrm{C} \pm 2^{\circ} \mathrm{C}$. For some experiments, the seedlings were raised in continuous dark for three days and then used for treatment, which reflected the analysis of light induced chlorophyll biosynthesis. For $\mathrm{Zn}$ treatment, 4 uniformly grown seedlings were transferred to $40 \mathrm{ml}$ of $0-5 \mathrm{mM}$ $\mathrm{ZnCl}_{2}$ solution contained in small petri plates for $24 \mathrm{~h}$ in continuous light as 
above and the treated seedlings were used for various analyses.

\subsection{Analytical Procedures}

Determination of growth and $\mathrm{Zn}$ content-Treated seedlings were used to analyze $\mathrm{Zn}$ content, fresh weight, dry weight, number of roots, weight and length of root and shoot. For $\mathrm{Zn}$ content analysis, root and shoot tissue of the seedlings were dried in oven at $80^{\circ} \mathrm{C}$ for 72 hours. The dried material $(400 \mathrm{mg})$ was wet digested with $5 \mathrm{ml}$ of conc. $\mathrm{HNO}_{3}$ and diluted $5 \times$ to $50 \times$ times i.e. ( $5 \times$ (control), $10 \times(0.001,0.01,0.1 \mathrm{mM}), 20 \times(1$ and $2 \mathrm{mM})$ and $50 \times(5 \mathrm{mM})$ with distil water. $\mathrm{Zn}$ content was determined by using atomic absorption spectrophotometer, make "GBC, Scientific Equipment Ltd-AVANTA".

Biochemical parameters-Total protein and RNA content of root and shoot tissue were measured by the method of [12] and [13], respectively. For protein content analysis, treated tissues were first boiled with and then extracted using $5.0 \mathrm{ml}$ of $80 \%$ ethanol for each step. The extract was centrifuged at $5000 \mathrm{rpm}$ for $10 \mathrm{~min}$ and the pellet was suspended in $5.0 \mathrm{ml}$ of 10\% TCA for $30 \mathrm{~min}$ and again centrifuged similarly. The resulting pellet was dissolved in $5.0 \mathrm{ml}$ of $0.1 \mathrm{~N} \mathrm{NaOH}$ and kept for at least $1 \mathrm{hr}$. After centrifugation, the supernatant was used for protein estimation with Folin Ciocaulteau's phenol reagent. For RNA extraction similar $80 \%$ ethanol treatment was used and then the pellet was suspended in 2.0 $\mathrm{ml}$ of $1 \%$ PCA mixed thoroughly and centrifuged. The pellet was treated with 5.0 $\mathrm{ml}$ of ethanol: diethyl ether: chloroform (2:2:1 v/v) mixture and then centrifuged. Three $\mathrm{ml}$ of $0.3 \mathrm{~N} \mathrm{KOH}$ was added to the residue and was incubated at $37^{\circ} \mathrm{C}$ for $18 \mathrm{hr}$. Next the $\mathrm{pH}$ was adjusted to 2.0 using $1 \mathrm{~N} \mathrm{PCA}$, centrifuged and appropriately diluted supernatent was used to estimate total RNA by orcinol reagent. For proline content determination, method of [14] was used.

Chlorophyll extraction and estimation-Pigments were extracted from the treated shoot tissue using $80 \%$ acetone and estimated spectrophotometrically by measuring the absorbance at $470 \mathrm{~nm}, 646 \mathrm{~nm}$, and $663 \mathrm{~nm}$. The pigment content was calculated using the following equations according to the method of [15].

$$
\begin{gathered}
\text { Chl a }\left(\mu \mathrm{g} \mathrm{ml}^{-1}\right)=12.21\left(\mathrm{~A}_{663}\right)-2.81\left(\mathrm{~A}_{646}\right) \\
\operatorname{Chl~b}\left(\mu \mathrm{g} \mathrm{ml}^{-1}\right)=20.13\left(\mathrm{~A}_{646}\right)-5.03\left(\mathrm{~A}_{663}\right) \\
\text { Total Chlorophyll }=\mathrm{Chl} \mathrm{a}+\mathrm{Chl} \mathrm{b} \\
\text { Caratenoids }\left(\mu \mathrm{g} \mathrm{ml}^{-1}\right)=1000\left(\mathrm{~A}_{470}\right)-3.27(\mathrm{Chl} \mathrm{a})-104(\mathrm{Chl} \mathrm{b}) / 229 .
\end{gathered}
$$

ALA content determination-Estimation was performed according to the method of [16]. For extraction of ALA, shoot tissue was extracted with $1 \mathrm{M}$ sodium acetate buffer. Homogenate was further centrifuged at 10,000 rpm for 10 $\min$ at $4^{\circ} \mathrm{C}$. ALA was reacted with ethyl acetoacetate followed by modified Ehlrich reagent for estimation. Color formation was measured at absorbance 555 nm on Shimadzu UV-1800 spectrophotometer.

ALA Formation-method of [16] was used to estimate the activity. Light and dark grown seedlings were used which were further incubated with levulinic acid 
which is responsible for inhibition of ALA synthesis. Incubation was performed in light and dark conditions. Modified Ehlrich reagent was used to estimate amount of ALA as above.

ALAD assay-ALAD activity was assayed spectrophometrically by estimating the amount of PBG (porphobilinogen) formed using modified Ehlrich reagent [17] according to the method of [18]. Treated shoot was extracted in $50 \mathrm{mM}$ Tris $\mathrm{HCl}$ buffer (pH 8.2) containing $10 \mathrm{mM}$ DTT. Extract was centrifuged at 15,000 $\mathrm{rpm}$ for $30 \mathrm{~min}$ at $4^{\circ} \mathrm{C}$ and supernatant was used as enzyme preparation. Reaction mixture of ALA, enzyme and $\mathrm{MgCl}_{2}$ was used to which TCA was added to stop the reaction. One unit of enzyme activity is defined as $1 \mathrm{nmol}$ of PBG formed per hour.

\subsection{Data Analysis}

Data presented in the paper are average of at least four independent experiments with \pm S.E. Significance of difference obtained for various treatments was tested by the Student's t-test. Compound correlation was calculated by Graphpad Prism 7.04.

\section{Results}

\subsection{Effect on Zn Accumulation in Root and Shoot of Maize Seedlings}

Supply of 0 - $5 \mathrm{mM} \mathrm{ZnCl}_{2}$ to three days old maize seedlings for $24 \mathrm{~h}$ resulted in concentration dependent increase in accumulation of $\mathrm{Zn}$ in root as well as shoot tissue with the effect being more substantial in the former (Figure 1). Sharp increase in $\mathrm{Zn}$ content in root tissue was observed at/above $0.1 \mathrm{mM}$, while in shoot

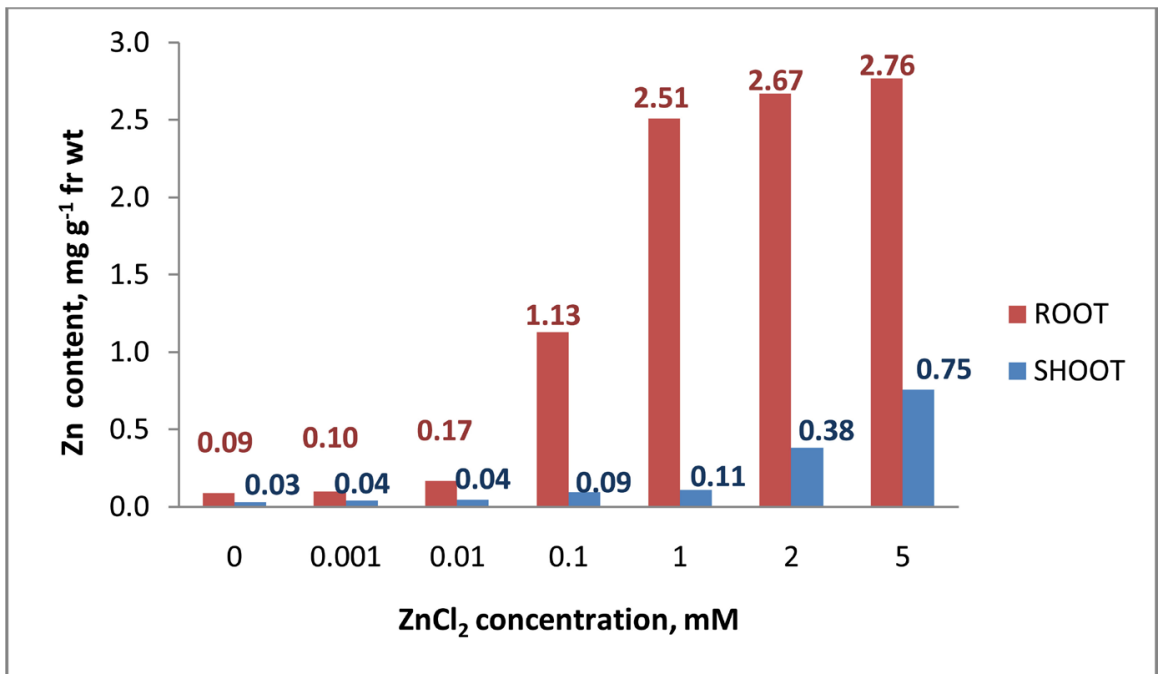

Three days old maize seedlings were treated with varying concentrations of $\mathrm{ZnCl}_{2}$ for $24 \mathrm{~h}$ at continuous light intensity of $30 \mathrm{Wm}^{-2}$ and temperature $26^{\circ} \mathrm{C} \pm 2^{\circ} \mathrm{C}$ and $\mathrm{Zn}$ content of root and shoot tissue was measured.

Figure 1. Effect of supply of $\mathrm{ZnCl}_{2}$ on accumulation of $\mathrm{Zn}$ in root and shoot tissue of the seedlings. 
tissue the increase was gradual; hence, perfect correlation resulted for later with $\mathrm{R}^{2}$ values being 0.591 and 0.976 , respectively (Figure 1 ).

\subsection{Effect of $\mathrm{ZnCl}_{2}$ on Growth and Biochemical Parameters of Maize Seedlings}

Zinc treatment of maize seedlings reduced significantly the fresh wt of the seedlings at higher concentrations of $1-5 \mathrm{mM}$, while the dry wt was reduced slightly (Table 1 ). Root parameters, like number and length were decreased more prominently and significantly in the concentration range of 0.1 to $5 \mathrm{mM}$ $\mathrm{Zn}$, but effect on shoot length was less severe and less significant (Table 1). Further, root wt was decreased more prominently and significantly than shoot weight. Moreover, all the growth parameters were correlated with $\mathrm{Zn}$ treatment with $\mathrm{R}^{2}$ values being in the range of 0.542 (For root length) to 0.744 (For shoot $w t)$.

Incubation of maize seedlings with $\mathrm{ZnCl}_{2}$ increased the protein content in both the root as well as shoot tissue with the effect being more prominent and significant in former (Table 2). Proline content was also increased in both the tissue with more significant change in roots (Table 2). The RNA content in shoot tissue was decreased, while it was increased in root issue but the effect was not significant except at $1 \mathrm{mM} \mathrm{Zn}$ (Table 2).

Compound correlation analyses yielded correlation between each pair of the parameters. Thus, in root tissue a perfect correlation of $\mathrm{Zn}$ content with root wt and protein and also between root wt and protein was observed having the values $-0.989,0.947$ and -0.969 , respectively (Table $3(\mathrm{a})$ ). For $\mathrm{Zn}$ content, root wt and protein with RNA and proline, strong correlation with values being in the range of 0.654 to 0.740 resulted, however between RNA and proline there was no correlation (Table 3(a)). In shoot tissue perfect correlation was observed for $\mathrm{Zn}$ content and shoots wt with proline having the values 0.939 and -0.949 , respectively (Table $3(\mathrm{~b})$ ). Very strong correlation of shoot wt with $\mathrm{Zn}$ content

Table 1. Effect of supply of $\mathrm{ZnCl}_{2}$ on fresh wt, dry wt, root no., root and shoot length, root and shoot wt of the seedlings. Three days old maize seedlings were treated with varying concentrations of $\mathrm{ZnCl}_{2}$ for $24 \mathrm{~h}$ at continuous light intensity of $30 \mathrm{Wm}{ }^{-2}$ and temperature $26^{\circ} \mathrm{C} \pm 2^{\circ} \mathrm{C}$ and various growth parameters were measured.

\begin{tabular}{|c|c|c|c|c|c|c|c|}
\hline $\mathrm{ZnCl}_{2}$ conc, $\mathrm{mM}$ & Fresh wt, mg & Dry wt, mg & Root No & Root length, $\mathrm{cm}$ & Shoot length, cm & Root wt, mg & Shoot wt, mg \\
\hline 0.0 & $612 \pm 9(100)$ & $271 \pm 11(100)$ & $5 \pm 0.2(100)$ & $5.7 \pm 0.3(100)$ & $2.9 \pm 0.4(100)$ & $114 \pm 10(100)$ & $122 \pm 10(100)$ \\
\hline 0.001 & $612 \pm 10(100)$ & $263 \pm 10(97)$ & $5 \pm 0.2(100)$ & $4.8 \pm 0.5(84)$ & $2.9 \pm 0.4(100)$ & $109 \pm 13(96)$ & $108 \pm 6(89)$ \\
\hline 0.01 & $612 \pm 15(100)$ & $259 \pm 8(96)$ & $5 \pm 0.4(100)$ & $4.7 \pm 0.4(82)$ & $2.3 \pm 0.1(79)$ & $101 \pm 13(89)$ & $106 \pm 2(87)$ \\
\hline 0.1 & $604 \pm 19$ (99) & $254 \pm 19(94)$ & $3 \pm 0.2^{* *}(60)$ & $3.3 \pm 0.1^{\star \star}(58)$ & $2.3 \pm 0.2(79)$ & $82 \pm 9(72)$ & $95 \pm 8(78)$ \\
\hline 1 & $544 \pm 21^{\star}(89)$ & $251 \pm 9(93)$ & $3 \pm 0.2^{* *}(60)$ & $3.0 \pm 0.3^{\star \star}(53)$ & $2.1 \pm 0.1(72)$ & $56 \pm 5^{\star \star}(49)$ & $82 \pm 6^{*}(67)$ \\
\hline 2 & $535 \pm 29(87)$ & $247 \pm 12(91)$ & $3 \pm 0.1^{\star *}(60)$ & $2.8 \pm 0.1^{\star *}(49)$ & $1.6 \pm 0.1^{*}(55)$ & $46 \pm 4^{\star \star}(40)$ & $77 \pm 7^{\star}(63)$ \\
\hline 5 & $528 \pm 12^{\star *}(86)$ & $241 \pm 15(89)$ & $2 \pm 0.2^{\star * \star}(40)$ & $2.3 \pm 0.2^{\star * *}(40)$ & $1.5 \pm 0.1^{\star}(52)$ & $39 \pm 3^{\star *}(34)$ & $62 \pm 8^{\star *}(51)$ \\
\hline $\mathbf{R}^{2}$ value & 0.681 & 0.659 & 0.597 & 0.542 & 0.659 & 0.659 & 0.744 \\
\hline
\end{tabular}

Values relative to control are given in parentheses. The level of significance tested was denoted as $\mathrm{p}$ values ${ }^{\star}<0.05,{ }^{*}<0.01,{ }^{* *}<0.001$. 
Table 2. Effect of supply of $\mathrm{ZnCl}_{2}$ on total protein, RNA and proline content of root and shoot tissue of the seedlings. Three days old maize seedlings were treated with varying concentrations of $\mathrm{ZnCl}_{2}$ for $24 \mathrm{~h}$ at continuous light intensity of $30 \mathrm{Wm} \mathrm{Wn}^{-2}$ temperature $26^{\circ} \mathrm{C} \pm 2{ }^{\circ} \mathrm{C}$ and various biochemical parameters were measured.

\begin{tabular}{|c|c|c|c|c|c|c|}
\hline \multirow{2}{*}{$\begin{array}{c}\mathrm{ZnCl}_{2} \\
\text { ]conc, } \mathrm{mM}\end{array}$} & \multicolumn{3}{|c|}{ Root } & \multicolumn{3}{|c|}{ Shoot } \\
\hline & $\begin{array}{l}\text { Total protein, } \\
\mathrm{mg} \mathrm{g}^{-1} \text { fr wt }\end{array}$ & $\begin{array}{l}\text { Total RNA, } \\
\mathrm{mg} \mathrm{g}^{-1} \text { fr wt }\end{array}$ & $\begin{array}{c}\text { Proline, } \\
\mu \mathrm{g} \mathrm{g}^{-1} \text { fr wt }\end{array}$ & $\begin{array}{l}\text { Total protein, } \\
\mathrm{mg} \mathrm{g}^{-1} \text { fr wt }\end{array}$ & $\begin{array}{l}\text { Total RNA, } \\
\mathrm{mg} \mathrm{g}^{-1} \text { fr wt }\end{array}$ & $\begin{array}{c}\text { Proline, } \\
\mu \mathrm{g} \mathrm{g}^{-1} \text { fr wt }\end{array}$ \\
\hline 0.0 & $6.0 \pm 0.4(100)$ & $18.1 \pm 1.6(100)$ & $259 \pm 14(100)$ & $6.8 \pm 0.4(100)$ & $12.3 \pm 1.3(100)$ & $171 \pm 17(100)$ \\
\hline 0.001 & $5.8 \pm 0.4(97)$ & $16.0 \pm 1.9(88)$ & $358 \pm 43(138)$ & $6.9 \pm 0.5(102)$ & $10.6 \pm 0.7(86)$ & $183 \pm 24(107)$ \\
\hline 0.01 & $6.4 \pm 0.5(106)$ & $15.5 \pm 2.7(86)$ & $399 \pm 14^{\star * *}(154)$ & $6.5 \pm 0.4(96)$ & $9.9 \pm 0.8(81)$ & $185 \pm 14(108)$ \\
\hline 0.1 & $8.6 \pm 1.1(143)$ & $24.0 \pm 3.2(133)$ & $342 \pm 40(132)$ & $6.5 \pm 0.1(96)$ & $9.6 \pm 0.8(78)$ & $199 \pm 22(116)$ \\
\hline 1 & $9.6 \pm 0.7^{\star \star}(160)$ & $22.4 \pm 0.4^{\star}(124)$ & $381 \pm 82(147)$ & $8.7 \pm 1.2(128)$ & $9.3 \pm 1.8(76)$ & $236 \pm 23(138)$ \\
\hline 2 & $12.9 \pm 1.5^{\star *}(215)$ & $21.4 \pm 1.4(118)$ & $405 \pm 41^{\star *}(156)$ & $9.2 \pm 0.45^{\star}(135)$ & $9.7 \pm 1.7(79)$ & $237 \pm 33(139)$ \\
\hline 5 & $13.3 \pm 1.2^{\star * *}(222)$ & $21.3 \pm 1.1(118)$ & $456 \pm 42^{* *}(176)$ & $8.4 \pm 0.60(124)$ & $9.2 \pm 1.5(75)$ & $310 \pm 37^{\star *}(181)$ \\
\hline
\end{tabular}

Values relative to control are given in parentheses. The level of significance tested was denoted as $\mathrm{p}$ values ${ }^{*}<0.05,{ }^{* *}<0.01,{ }^{* *}<0.001$.

Table 3. (a) Compound Correlation data of Zn Content, Root wt, Protein, RNA, Proline content in root tissues. (b) Compound Correlation data of Zn Content, Shoot wt, Protein, RNA, Proline content in shoot tissues.

(a)

\begin{tabular}{|c|c|c|c|c|c|}
\hline & Zn content & Root wt & Protein & RNA & Proline \\
\hline Zn content & & -0.989 & 0.947 & 0.729 & 0.654 \\
\hline Root wt & & & -0.969 & -0.695 & -0.740 \\
\hline Protein & & & & 0.656 & 0.700 \\
\hline RNA & & & & & 0.169 \\
\hline Proline & & & & & \\
\hline
\end{tabular}

(b)

\begin{tabular}{|c|c|c|c|c|c|}
\hline & Zn content & Shoot wt & Protein & RNA & Proline \\
\hline Zn content & & -0.854 & 0.632 & -0.494 & 0.939 \\
\hline Shoot wt & & & -0.787 & 0.826 & -0.949 \\
\hline Protein & & & & -0.481 & 0.727 \\
\hline RNA & & & & & -0.670 \\
\hline Proline & & & & & \\
\hline
\end{tabular}

$(-0.854)$ and RNA (0.826), strong correlation of protein with Zn content (0.632), shoot wt (-0.787) and proline (0.727) and between RNA and proline -0.670) also resulted (Table $3(\mathrm{~b})$ ). While for RNA with $\mathrm{Zn}$ content and protein lesser correlation was observed.

\subsection{Effect of $\mathrm{ZnCl}_{2}$ on Chlorophyll Biosynthesis in Shoot Tissue of Light Grown Maize Seedlings}

Treatment of light grown maize seedlings with $\mathrm{ZnCl}_{2}$ at $1-5 \mathrm{mM}$ increased the 
chlorophyll, carotenoid and ALA content with significant effect for carotenoids at $5 \mathrm{mM} \mathrm{Zn}$ and for ALA at 2 and $5 \mathrm{mM}$ both (Table 4(a)). To analyse ALA formation activity $\mathrm{ZnCl}_{2}$ treated seedlings were incubated with $60 \mathrm{mM}$ levulinic acid for $4 \mathrm{~h}$ either in light or dark corresponding to chloroplastic and mitochondrial activities respectively, the ALA accumulation in both was slightly enhanced and exerted no correlation (Table 4(b)), However, $\mathrm{ZnCl}_{2}$ significantly increased ALAD activity at all the concentrations (Table 4(b)).

The compound correlation analysed for chlorophyll and carotenoid contents with $\mathrm{Zn}$ content exhibited very strong +ve correlation (0.862) but had shown very strong -ve correlation ( -0.836 and -0.807$)$ with shoot wt (Table 5(a)). For ALA with $\mathrm{Zn}$ content the correlation was strong being 0.703 and with shoot wt it was

Table 4. (a) Effect of supply of $\mathrm{ZnCl}_{2}$ on total chlorophylls, carotenoids and ALA content in shoot tissue of the light grown seedlings. Three days old maize seedlings were treated with varying concentrations of $\mathrm{ZnCl}_{2}$ for $24 \mathrm{~h}$ at continuous light intensity of $30 \mathrm{Wm}^{-2}$ and temperature $26^{\circ} \mathrm{C} \pm 2{ }^{\circ} \mathrm{C}$. (b) Effect of $\mathrm{ZnCl}_{2}$ on ALAS and ALAD activity in shoot tissue of light grown seedlings. Three days old maize seedlings were treated with varying concentrations of $\mathrm{ZnCl}_{2}$ for $24 \mathrm{~h}$ at continuous light intensity of $30 \mathrm{Wm}^{-2}$ and temperature $26^{\circ} \mathrm{C} \pm 2{ }^{\circ} \mathrm{C}$.

(a)

\begin{tabular}{cccc}
$\begin{array}{c}\mathrm{Z} \mathrm{ZnCl}_{2} \text { conc, } \\
\mathrm{mM}\end{array}$ & $\begin{array}{c}\text { Total chlorophylls, } \\
\mu \mathrm{g} \mathrm{g}^{-1} \mathrm{fr} \text { wt }\end{array}$ & $\begin{array}{c}\text { Carotenoids, } \\
\mathrm{g} \mathrm{g} \mathrm{g}^{-1} \mathrm{fr} w \mathrm{wt}\end{array}$ & $\begin{array}{c}\text { ALA content, } \\
\text { nmoles g-1 fr wt }\end{array}$ \\
\hline 0.0 & $207 \pm 8(100)$ & $23.3 \pm 2.4(100)$ & $234 \pm 13(100)$ \\
0.001 & $206 \pm 13(100)$ & $21.4 \pm 2.7(93)$ & $235 \pm 11(100)$ \\
0.01 & $211 \pm 13(102)$ & $24.3 \pm 1.8(104)$ & $260 \pm 18(111)$ \\
0.1 & $196 \pm 12.2(95)$ & $20.5 \pm 1.8(93)$ & $259 \pm 18(111)$ \\
1 & $240 \pm 12(116)$ & $29.0 \pm 1.7(126)$ & $352 \pm 70(150)$ \\
2 & $229 \pm 16(111)$ & $26.8 \pm 3.8(117)$ & $312 \pm 13^{*}(133)$ \\
5 & $270 \pm 19(131)$ & $35.9 \pm 1.7^{* *}(157)$ & $351 \pm 16^{* *}(150)$ \\
\hline
\end{tabular}

Values relative to control are given in parentheses. The level of significance tested was denoted as $\mathrm{p}$ values * $<0.05,{ }^{* *}<0.01,{ }^{* *}<0.001$.

(b)

\begin{tabular}{cccc}
\hline $\begin{array}{c}\mathrm{ZnCl}_{2} \text { conc, } \\
\mathrm{mM}\end{array}$ & $\begin{array}{c}\text { ALAS activity, nmoles } \\
\text { ALA formed } \mathrm{h}^{-1} \mathrm{~g}^{-1} \text { fr wt } \\
\text { In Light }\end{array}$ & $\begin{array}{c}\text { ALAS activity, nmoles } \\
\text { ALA formed } \mathrm{h}^{-1} \mathrm{~g}^{-1} \text { fr wt } \\
\text { In Dark }\end{array}$ & $\begin{array}{c}\text { ALAD activity, } \\
\text { nmoles PBG formed } \mathrm{h}^{-1} \mathrm{~g}^{-1} \text { fr wt }\end{array}$ \\
\hline 0 & $88 \pm 6(100)$ & $83 \pm 5(100)$ & $200 \pm 7(100)$ \\
0.001 & $88 \pm 3(100)$ & $93 \pm 8(112)$ & $249 \pm 4^{* *}(125)$ \\
0.1 & $99 \pm 8(113)$ & $93 \pm 7(112)$ & $263 \pm 4^{* *}(132)$ \\
1 & $92 \pm 5(105)$ & $91 \pm 7(110)$ & $279 \pm 5^{* * *}(140)$ \\
5 & $97 \pm 5(111)$ & $96 \pm 2(116)$ & $345 \pm 11^{* * *}(173)$
\end{tabular}

Values relative to control are given in parentheses. The level of significance tested was denoted as $\mathrm{p}$ values * $<0.05,{ }^{* *}<0.01,{ }^{* * *}<0.001$. 
Table 5. (a) Compound Correlation data of $\mathrm{Zn}$ content, shoot wt, total chlorophyll, carotenoids, ALA content in shoot tissues of light grown maize seedlings; (b) Compound Correlation data of $\mathrm{Zn}$ content, shoot wt, ALAS light and dark treated and ALAD in shoot tissues of light grown maize seedlings.

(a)

\begin{tabular}{|c|c|c|c|c|c|}
\hline & Zn content & Shoot wt & Chlorophyll & Carotenoid & ALA \\
\hline Zn content & & -0.854 & 0.862 & 0.862 & 0.703 \\
\hline Shoot wt & & & -0.836 & -0.807 & -0.908 \\
\hline Chlorophyll & & & & 0.992 & 0.891 \\
\hline Carotenoid & & & & & 0.870 \\
\hline ALA & & & & & \\
\hline
\end{tabular}

(b)

\begin{tabular}{|c|c|c|c|c|c|}
\hline & Zn content & Shoot wt & ALAS in light & ALAS in dark & ALAD \\
\hline Zn content & & -0.830 & 0.527 & 0.590 & 0.875 \\
\hline Shoot wt & & & -0.681 & -0.776 & -0.979 \\
\hline ALAS in light & & & & 0.624 & 0.658 \\
\hline ALAS in dark & & & & & 0.852 \\
\hline ALAD & & & & & \\
\hline
\end{tabular}

perfect being -0.908 (Table 5(a)). Further, observed correlation of chlorophyll with carotenoid and ALA was perfect being 0.992 and 0.891 , respectively and between carotenoid and ALA was 0.870 (Table 5(a)). Positive correlation for $\mathrm{Zn}$ content with ALA formation in light and dark was lesser (0.527 and 0.590), but for ALAD activity was very strong (0.875). Observed correlation of shoot wt with these parameters was negative and stronger being perfect with ALAD (-0.979) (Table 5(b)). Further, ALAD activity exerted strong correlation with ALA formation in light and dark both being 0.658 and 0.852 , respectively and stronger with later (Table 5(b)).

\subsection{Effect of $\mathrm{ZnCl}_{2}$ on Chlorophyll Metabolism in Shoot Tissue of Dark Grown Maize Seedlings}

Treatment of dark grown maize seedlings with $\mathrm{ZnCl}_{2}$ decreased the chlorophyll content slightly and the carotenoid content remained unaffected, while the ALA content was significantly increased at 2 and $5 \mathrm{mM} \mathrm{ZnCl}_{2}$ (Table 6(a)). The observed correlation with $\mathrm{Zn}$ treatment was found to be very strong for ALA content with $\mathrm{R}^{2}$ value of 0.818 (Table $6(\mathrm{a})$ ). When maize seedlings were treated with $\mathrm{ZnCl}_{2}$, ALA formation activity both in light and dark and ALAD activity were enhanced at 1 and $5 \mathrm{mM}$ showing significant increase for ALA formation in light at $1 \mathrm{mM}$ treatment only (Table $6(\mathrm{~b}))$. $\mathrm{Zn}$ treatment and these parameters also exerted strong correlation with $\mathrm{R}^{2}$ value of $0.960,0.728$ and 0.691 respectively (Table 6(b)). 
Table 6. (a) Effect of supply of $\mathrm{ZnCl}_{2}$ on total chlorophylls, carotenoid and ALA content in shoot tissue of the dark grown seedlings. Three days old maize seedlings were treated with varying concentrations of $\mathrm{ZnCl}_{2}$ for $24 \mathrm{~h}$ at continuous light intensity of $30 \mathrm{Wm}^{-2}$ and temperature $26^{\circ} \mathrm{C} \pm 2{ }^{\circ} \mathrm{C}$. (b) Effect of $\mathrm{ZnCl}_{2}$ on ALAS and ALAD activity in shoot tissue of dark grown seedlings. Three days old maize seedlings were treated with varying concentrations of $\mathrm{ZnCl}_{2}$ for $24 \mathrm{~h}$ at continuous light intensity of $30 \mathrm{Wm}^{-2}$ and temperature $26^{\circ} \mathrm{C} \pm 2{ }^{\circ} \mathrm{C}$.

(a)

\begin{tabular}{cccc}
$\mathrm{ZnCl}_{2}$ conc., $\mathrm{mM}$ & Total chlorophylls, $\mu \mathrm{g} \mathrm{g}^{-1}$ fr wt. & Carotenoids, $\mu \mathrm{g} \mathrm{g}^{-1} \mathrm{fr} w t$. & $\mathrm{ALA}, \mathrm{nmoles} \mathrm{g}^{-1} \mathrm{fr} w \mathrm{wt}$ \\
\hline 0.0 & $115 \pm 5(100)$ & $16.0 \pm 1.3(100)$ & $333 \pm 8(100)$ \\
0.001 & $94 \pm 7(82)$ & $15.9 \pm 1.0(99)$ & $346 \pm 9(104)$ \\
0.01 & $108 \pm 9(94)$ & $15.5 \pm 1.1(97)$ & $355 \pm 13(107)$ \\
0.1 & $101 \pm 9(88)$ & $15.4 \pm 1.1(96)$ & $375 \pm 14(113)$ \\
1 & $121 \pm 7(105)$ & $15.6 \pm 1.4(98)$ & $410 \pm 15(123)$ \\
2 & $109 \pm 12(95)$ & $16.0 \pm 1.9(100)$ & $449 \pm 5^{\star *}(135)$ \\
5 & $106 \pm 9(92)$ & $15.9 \pm 0.6(99)$ & $475 \pm 9^{* *}(143)$ \\
$\mathbf{R}^{2}$ value & $\mathbf{0 . 0 0 7}$ & 0.152 & 0.818
\end{tabular}

Values relative to control are given in parentheses. The level of significance tested was denoted as $\mathrm{p}$ values * $<0.05$, $^{* *}<0.01^{* * *}<0.001$.

(b)

\begin{tabular}{cccc}
$\begin{array}{c}\mathrm{ZnCl}_{2} \\
\text { conc, } \mathrm{mM}\end{array}$ & $\begin{array}{c}\text { ALAS activity, nmoles ALA } \\
\text { formed } \mathrm{h}^{-1} \mathrm{~g}^{-1} \text { fr wt } \\
\text { In Light }\end{array}$ & $\begin{array}{c}\text { ALAS activity,moles ALA } \\
\text { formed } \mathrm{h}^{-1} \mathrm{~g}^{-1} \text { fr wt } \\
\text { In Dark }\end{array}$ & $\begin{array}{c}\text { ALAD activity, nmoles PBG } \\
\text { formed } \mathrm{h}^{-1} \mathrm{~g}^{-1} \text { fr wt }\end{array}$ \\
\hline 0 & $64 \pm 4(100)$ & $77 \pm 5(100)$ & $140 \pm 25(100)$ \\
0.001 & $69 \pm 7(108)$ & $71 \pm 5(92)$ & $149 \pm 10(107)$ \\
0.1 & $74 \pm 7(116)$ & $68 \pm 8(88)$ & $159 \pm 10(114)$ \\
1 & $80 \pm 3^{*}(125)$ & $88 \pm 7(114)$ & $168 \pm 6(121)$ \\
5 & $108 \pm 19(169)$ & $96 \pm 10(125)$ & $180 \pm 3(129)$ \\
$\mathbf{R}^{2}$ value & $\mathbf{0 . 9 6 0}$ & $\mathbf{0 . 7 2 8}$ & 0.691 \\
\hline
\end{tabular}

Values relative to control are given in parentheses. The level of significance tested was denoted as $\mathrm{p}$ values * $<0.05,{ }^{* *}<0.01,{ }^{* * *}<0.001$.

\section{Discussion}

\subsection{Growth Effects}

$\mathrm{Zn}$ is an essential micronutrient for plants, but is toxic at high concentrations, hence its effect on growth depends upon the concentration. Thus decrease in growth due to $\mathrm{Zn}$ supply has been reported in ryegrass [5], sugar beet [7] cluster bean [6] and Sorgham [8], however, in mungbean [19] and Eruca sativa [9] increased growth resulted. In the present study, with the supply of $\mathrm{ZnCl}_{2}$ to 3 days old maize seedlings, the effect on $\mathrm{Zn}$ accumulation and morphological and biochemical growth parameters have been analysed. The $\mathrm{Zn}$ treatment led to gradually increased accumulation of $\mathrm{Zn}$ in the shoot tissue, while in the root tissue 
substantial increase was observed at/and above $0.1 \mathrm{mM} \mathrm{ZnCl}_{2}$ (Figure 1). Also the root parameters were significantly reduced at/and above $0.1 \mathrm{mM} \mathrm{ZnCl}$ (Table 1 ). Thus $\mathrm{Zn}$ supply significantly reduced the overall growth of maize seedlings mostly at $1-5 \mathrm{mM} \mathrm{ZnCl}_{2}$ exerting strong correlation and the observed effect was more substantial for root tissue. Amongst biochemical parameters, increase in protein and proline content was more prominent in root tissue than the shoot, while RNA content was reduced in shoot tissue (Table 2). Reduction in RNA may be due to faster degradation and the increased protein due to translation of pre synthesized RNA. It seems that enhanced protein and proline synthesis is associated with $\mathrm{Zn}$ effects in root, as these contents are significantly increased. Increased levels of protein may be required for the synthesis of stress induced proteins [20] and of proline, for osmotic adjustments in response to $\mathrm{Zn}$. Accumulation of proline is well documented against various stresses in plants, such as, Spinacia oleracea [21] and Cucurbeta pepo [22]. Further, the observed correlation for $\mathrm{Zn}$ accumulation in root with as well as between root wt and protein was perfect (Table 3(a)). Also perfect correlation for $\mathrm{Zn}$ accumulation in shoot and shoot wt with proline resulted (Table 3(b)). Thus the $\mathrm{Zn}$ accumulation and growth effect in maize depends upon the tissue with root as the target site.

\subsection{Chlorophyll Biosynthesis Effects}

Chlorophylls, the vital photosynthetic pigments and carotenoids, the light harvesting pigments in green tissues affect the overall photosynthetic activity and hence the growth and development of the plant. Chlorosis due to both $\mathrm{Zn}$ deficiency [23] and toxicity [2] have been observed in plants. Reports of decrease in chlorophyll content due to Zn supply in sugar beet [7], cluster bean [6] and Sorgham [8] but increase in mungbean [19] has been documented. In the present study, Zn treatment to light grown seedlings prominently increased the chlorophyll and carotenoid content, while in dark grown seedlings it had marginal/no effect (Table 4(a) and Table 6(a)). This indicated that the steady state level of the pigments is getting affected by $\mathrm{Zn}$ rather than inducible level. Content of ALA, a regulatory metabolite and universal precursor for all the tetrapyrroles, was increased at higher $\mathrm{Zn}$ concentrations in both the regimes (Table 4(a) and Table 6(a)). Thus increased synthesis of chlorophylls as well as other heme containing proteins is likely to result by $\mathrm{Zn}$ supply. Increased ALA content may involve enhanced synthesis and the ALA synthesis was also found to be increased in both the regimes in light as well as dark that corresponds to chloroplastic and mitochondrial activities respectively, however, the effect was non significant (Table 4(b) and Table 6(b)). Thus it seems that $\mathrm{Zn}$ exerts lesser effect to enhance ALA synthesis. Further, Zn supply increased ALAD activity of light as well as dark grown seedlings being significant in former (Table 4(b) and Table 6(b)). Hence, the next step of chlorophyll biosynthetic pathway catalysed by ALAD involving formation of porphobilinogen from ALA seems to get affected 
by $\mathrm{Zn}$. Further, ALADs from different sources are metalloenzymes that utilize a variety of divalent and monovalent cations [11] ALAD requires $\mathrm{Mg}^{2+}$ and $\mathrm{Zn}^{2+}$ for its activity [10] hence its activity is enhanced by $\mathrm{Zn}$ treatment. Moreover, in light grown seedlings the observed correlation for pigment content with $\mathrm{Zn}$ accumulation and shoot wt was very strong for both, +ve (0.862 and 0.862) and -ve (0.836 and 0.807), respectively (Table 5(a)). Also for ALA content and ALAD with shoot wt perfect -ve correlation resulted (Table 5(a) and Table 5(b)). Moreover, ALAD has been reported to be a substrate-modulated enzyme [24]. Hence, it is likely that during Zn treatment shoot growth and chlorophyll formation is mainly influenced by ALA and subsequently by ALAD in maize seedlings.

\section{Conclusion}

$\mathrm{ZnCl}_{2}$ treatment accumulated $\mathrm{Zn}$ in root as well as shoot tissue with more substantial increase in former. $\mathrm{Zn}$ supply reduced the overall growth of the maize seedlings at higher concentrations with more prominent effect in roots. Increase in protein and proline content by $\mathrm{Zn}$ was more prominent in root tissue than the shoot. $\mathrm{Zn}$ increased the chlorophyll, carotenoid and ALA content in the shoot tissue of light grown seedlings and the ALA content in dark grown seedlings also. Increase in ALA formation and ALAD activity also resulted by $\mathrm{Zn}$ being most significant in light grown seedlings. The results suggest that $\mathrm{Zn}$ accumulation and growth effect at higher $\mathrm{Zn}$ concentrations in maize depend upon the tissue with root as the target site and shoot growth are mainly influenced by ALA and subsequently ALAD in maize seedlings.

\section{Conflicts of Interest}

The authors declare no conflicts of interest regarding the publication of this paper.

\section{References}

[1] Jelakovic, S., Kopriva, S., Suss, K.H. and Schulz, G.E. (2003) Structure and Catalytic Mechanism of the Cytosolic D-ribulose-5-phosphate 3-epimerase from Rice. Journal of Molecular Biology, 326, 127-135. https://doi.org/10.1016/S0022-2836(02)01374-8

[2] Marschner, H. (1995) Mineral Nutrition of Higher Plants. Academic Press, London, Vol. 2, 889.

[3] Sagardoy, R., Vázquez, S., Florez-Sarasa, I.D., Albacete, A., Ribas-Carbó, M.J., Abadía, F.J. and Morales, F. (2010) Stomatal and Mesophyll Conductances to $\mathrm{CO}_{2}$ Are the Main Limitations to Photosynthesis in Sugar Beet (Beta vulgaris) Plants Grown with Excess Zinc. New Phytologist, 187, 145-158. https://doi.org/10.1111/j.1469-8137.2010.03241.x

[4] Cui, Y. and Zhao, N. (2011) Oxidative Stress and Change in Plant Metabolism of Maize (Zea mays L.) Growing in Contaminated Soil with Elemental Sulfur and Toxic Effect of Zinc. Plant Soil and Environment, 57, 34-39. https://doi.org/10.17221/193/2010-PSE 
[5] Bonnet, M., Camares, O. and Veisseire, P. (2000) Effect of Zinc and Influence of Acremonium lolli on Growth Parameters, Chlorophyll a Fluorescence and Antioxidant Enzyme Activity of Ryegrass (Lolium perenne L. cv Apollo). Journal of Experimental Botany, 51, 945-953.

[6] Manivasagaperumal, R., Balamurugan, S., Thiyagarajan, G. and Sekar, J. (2011) Effect of Zinc on Germination, Seedling Growth and Biochemical Content of Cluster Bean (Cyamopsis tetragonoloba (L.) Taub). Current Botany, 2, 11-15.

[7] Sagardoy, R., Morales, F., Lopez-Millan, A.F., Abadia, A. and Abadia, J. (2009) Effects of Zinc Toxicity on Sugar Beet (Beta vulgaris L.) Plants Grown in Hydroponics. Plant Biology, 11, 339-350. https://doi.org/10.1111/j.1438-8677.2008.00153.x

[8] Mirshekali, H., Hadi, H., Amirnia, R. and Verdiloo, H.K. (2012) Effect of Zinc Toxicity on Plant Productivity, Chlorophyll and Zn Contents of Sorghum (Sorghum Bicolor) and Common Lambsquarter (Chenopodium album). International Journal of Agriculture Research and Review, 2, 247-254.

[9] Ozdener, Y. and Aydin, B.K. (2010) The Effect of Zinc on the Growth and Physiological and Biochemical Parameters in Seedlings of Eruca sativa (L.) (Rocket). Acta Physiologiae Plantarum, 32, 469-476. https://doi.org/10.1007/s11738-009-0423-z

[10] Beale, S.I. (1999) Enzymes of Chlorophyll Biosynthesis. Photosynthesis Research, 60, 43-73. https://doi.org/10.1023/A:1006297731456

[11] Jaffe, E.K. (2000) The Porphobilinogen Synthase Family of Metalloenzymes. Acta Crystallographica, 56, 115-128. https://doi.org/10.1107/S0907444999014894

[12] Lowry, O.H., Rosebrough, N.J., Farr, A.C. and Randall, R.J. (1951) Protein Measurement with the Folin-Phenol Reagent. The Journal of Biological Chemistry, 193, 265-275.

[13] Webb, J.M. and Levy, H.B. (1958) New Developments in Chemical Determination of Nucleic Acid. In: Glick, D., Ed., Methods of Biochemical Analysis, Inter Science Publication, New York City, Vol. 6, 1-30. https://doi.org/10.1002/9780470110225.ch1

[14] Bates, L.S., Walderren, R.P. and Teare, I.D. (1973) Rapid Determination of Free Proline for Water-Studies. Plant Soil, 39, 205-207. https://doi.org/10.1007/BF00018060

[15] Lichtenthaler, H.K. and Welburn, A.R. (1983) Determination of Total Carotenoids and Chlorophylls a and b of Extracts in Different Solvents. Biochemical Society Transactions, 11, 591-592. https://doi.org/10.1042/bst0110591

[16] Tewari, A.K. and Tripathy, B.C. (1998) Temperature-Stress-Induced Impairment of Chlorophyll Biosynthetic Reactions in Cucmber and Wheat. Plant Physiology, 177, 851-858. https://doi.org/10.1104/pp.117.3.851

[17] Mauzerall, D. and Granik, S. (1956) The Occurrence and Determination of $\delta$-Aminoleveulinic Acid Dehydratase and Porophobilinogen in Urine. The Journal of Biological Chemistry, 219, 435-446.

[18] Jain, M. and Gadre, R. (2004) Inhibition of 5-Amino Levulinic Acid Dehydratase Activity by Arsenic in Excised Etiolated Maize Leaf Segments during Greening. Journal of Plant Physiology, 161, 251-255. https://doi.org/10.1078/0176-1617-00879

[19] Samreen, T., Humaria, S.H.U., Ullah, S. and Javid, M. (2017) Zn Effect on Growth Rate, Chlorophyll, Protein and Mineral Contents of Hydroponically Grown Mungbeans Plant (Vigna radiata). Arabian Journal of Chemistry, 10, S1802-S1807. https://doi.org/10.1016/j.arabjc.2013.07.005

[20] Hasan, M.K., Cheng, Y., Kanwar, M.K., Chu, X.Y., Ahammed, G.J. and Qi, Z.Y. (2017) Responses of Plant Proteins to Heavy Metal Stress-A Review. Frontiers in 
Plant Science, 8, 1492. https://doi.org/10.3389/fpls.2017.01492

[21] Mishra, S. and Agrawal, S.B. (2006) Interactive Effects between Supplemental UV-B Radiation and Heavy Metals on Growth and Biochemical Characterstics of Spinacea oleracea L. Brazilian Journal of Plant Physiology, 18, 1-8.

[22] Lalelou, F.S., Kolvanagh, J.S. and Fateh, M. (2013) Effect of Various Concentrations of Zinc on Chlorophyll, Starch, Soluble Sugars and Proline in Naked Pumpkin (Cucurbita pepo). International Journal of Farming and Allied Sciences, 2, 1198-1202.

[23] Tucker, R.M. (1999) Essential Plant Nutrients: Their Presence in North Carolina Soils and Role in Plant Nutrition. 1-9.

[24] Tchuinmogne, S.T., Hault, C., Auoules, A. and Balange, A.P. (1989) Inhibitory Effect of Gabaculine on 5-Aminolevulinnate Dehydratase in Raddish Seedlings. Plant Physiology, 90, 1293-1297. https://doi.org/10.1104/pp.90.4.1293 